\title{
List of Drawings
}

Drawingo from life by Jean Guérin 
Portrait of Blaise Cendrars (frontiopiece)

CHAPTER I

A Corner on Main Street, Los Angeles 16

Beverly Drive 22

Santa Monica Beach 28

CHAPTER II

Culver City (M.G.M.) 34

Grocery and Bakery 41

On the Road (Hitchhikers) 47

Thompson, Masseur to the Stars 54

Members of the Jazz Band Cendrars

(June Cruze and Ka Balzac) 59

Marlene Dietrich 66

CHAPTER III

The Famous Corner of Hollywood \& Vine 76

Entrance to the Studios (Universal) -

Helen Westey 81

The Window (Universal) 86

Restaurant (Universal) - Lunch with

Cendrars: Ed Arnold, Pinki Tomkin,

Helen Westey, etc. 91 
CHAPTER IV

At the Trocadero (encounter with Marlene Dietrich and Greta Garbo) 96

Irene Dunne Filming Show Boat 112

On Hollywood Boulevard (The wearers of dark glasses hope to be taken for stars incognito!) 123

CHAPTER V

Sandwich Stand 136

Jeanette MacDonald Filming San Francisco

(In the cooper's cap: Anita Loos) 141

Franz Lederer Filming Monsieur Sano-Gêne 146

CHAPTER VI

At Max Factor's 152

On the Beach 158

Stars at the Market 163

The Nightclub District 168

June Cruze 172

CHAPTER VII

The Famous Door 180

At the Alabam 185

At Louis Prima's 190

Departure (aboard the Wisconsin) 196 
